\title{
Chiral (cyclopentadienone)iron complexes with a stereogenic plane as pre-catalysts for the asymmetric hydrogenation of polar double bonds
}

\author{
Xishan Bai ${ }^{\mathrm{a}}$, Mattia Cettolin ${ }^{\mathrm{a}}$, Giulia Mazzoccanti ${ }^{\mathrm{b}}$, Marco Pierini, ${ }^{\mathrm{b}}$ Umberto Piarulli, ${ }^{\mathrm{c}}$ \\ Valentina Colombo ${ }^{\mathrm{a}}$, Alberto Dal Corso ${ }^{\mathrm{a}}$, Luca Pignataro ${ }^{\mathrm{a}, *}$ and Cesare Gennari ${ }^{\mathrm{a}, *}$ \\ ${ }^{a}$ Università degli Studi di Milano, Dipartimento di Chimica, via C. Golgi, 19 - 20133 Milano, Italy \\ ${ }^{b}$ Sapienza Università di Roma, Dipartimento di Chimica e Tecnologie del Farmaco, piazzale A. Moro, 5 - 00185 Roma, Italy \\ ${ }^{c}$ Università degli Studi dell'Insubria, Dipartimento di Scienza e Alta Tecnologia, via Valleggio, 11 - 22100 Como, Italy
}

\section{ARTICLE INFO}

Article history:

Received

Received in revised form

Accepted

Available online

Keywords:

Asymmetric hydrogenation

(Cyclopentadienone)iron complexes

Iron catalysis

Stereogenic plane

Polar double bonds

\section{ABSTRACT}

In this paper, we describe a small library of easy-to-prepare chiral (cyclopentadienone)iron precatalysts for enantioselective $\mathrm{C}=\mathrm{O}$ and $\mathrm{C}=\mathrm{N}$ hydrogenations. Starting from readily accessible achiral materials, six chiral (cyclopentadienone)iron complexes (1a-f) possessing a stereogenic plane were synthesized in racemic form. Based on the screening of pre-catalysts ( \pm )-1a-f in the hydrogenation of ketones and ketimines, we selected two complexes (1a and 1d) for resolution by semipreparative enantioselective HPLC. The absolute configuration of the separated enantiomers of 1a and 1d was assigned by XRD analysis (1a) and by comparison between experimental and DFT-calculated ECD and ORD spectra (1d). The enantiopure pre-catalysts $(S)$-1a and $(R)$-1d were tested in the asymmetric hydrogenation of several ketones and ketimines and showed good activity and modest enantioselectivity, the e.e. values ranging from very low to moderate $(54 \%)$.

2009 Elsevier Ltd. All rights reserved.

\section{Introduction}

In the search for sustainable catalytic methodologies, replacement of precious metals with base metals is receiving increasing attention by academic and industrial researchers. However, as far as homogeneous catalysis is concerned, the choice of the ligand is equally important as that of the metal. Indeed, use of costly and sophisticated ligands may offset the intrinsic advantage of employing a cheap metal. (Cyclopentadienone)iron complexes 1 (Scheme 1) represent a good balance between these two aspects because they combine iron - i.e., the cheapest, most abundant and least toxic transition metal [ 1 ] - with simple ligands such as $\mathrm{CO}$ and cyclopentadienones. The latter are readily prepared by condensation of $\alpha$-diketones with 1,3-disubstituted acetones or by cyclative carbonylation/complexation of diynes (directly affording the iron complexes) [2]. Additionally, unlike many other iron complexes used in catalysis, compounds $\mathbf{1}$ are very stable, which facilitates their purification (that can be performed by chromatography) and use. Under suitable conditions (Scheme 1 A) they can be converted in situ into the activated forms act-1 and 2 [3], which promote several reactions involving hydrogen transfer through the same pericyclic transition state (Scheme 1 B): i) reduction of polar double bonds by catalytic hydrogenation [3d-g,4a,c-f,5] or catalytic transfer hydrogenation [3a,4a-b,6]; ii) Oppenauer-type oxidation of alcohols [6b,e,7]; iii) redox-neutral hydrogen-borrowing reactions such as alcohol amination [8] and others [8a,9].

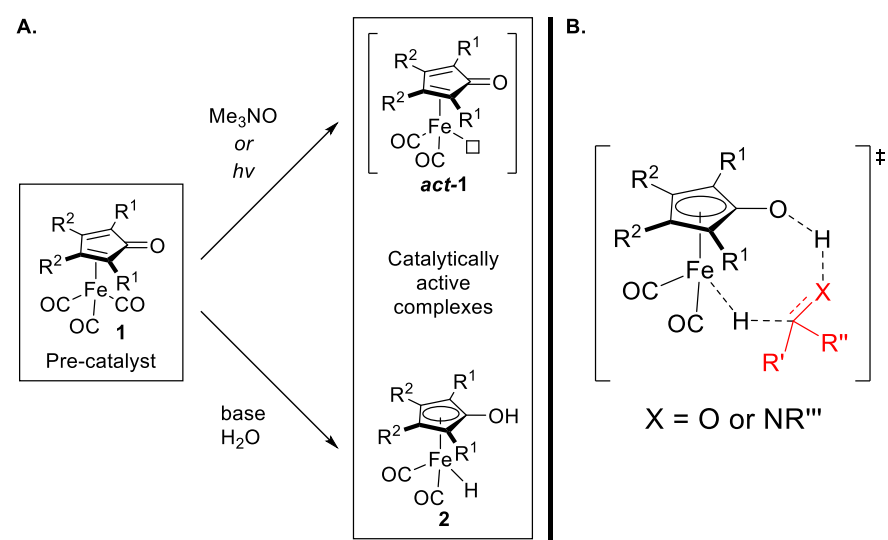

Scheme 1. A: in situ activation of (cyclopentadienone)iron complexes 1; B: TS of the reactions involving transfer of hydrogen promoted by the active complexes $\boldsymbol{a c t} \mathbf{- 1}$ and $\mathbf{2}$.

Very recently, the first applications of (cyclopentadienone)iron complexes to reactions not involving hydrogen transfer have also appeared in the literature [10].

Despite the blossoming interest for these complexes, their use in enantioselective catalysis is still very limited, with the notable exception of the enantioselective $\mathrm{C}=\mathrm{N}$ reductions reported by 
Beller et al., in which an achiral type-2 complex (i.e., the airsensitive activated form) is combined with a chiral phosphoric acid co-catalyst [3d-g]. Attempts to develop effective chiral type1 pre-catalysts met with only partial success, with poor or moderate e.e.'s obtained in the reduction of ketones and ketimines (Fig. 1). This is probably due to the difficulty to place the stereogenic group(s) of the complexes sufficiently close to the substrate in the pericyclic TS of reductions (see Scheme $1 \mathrm{~B}$ ).

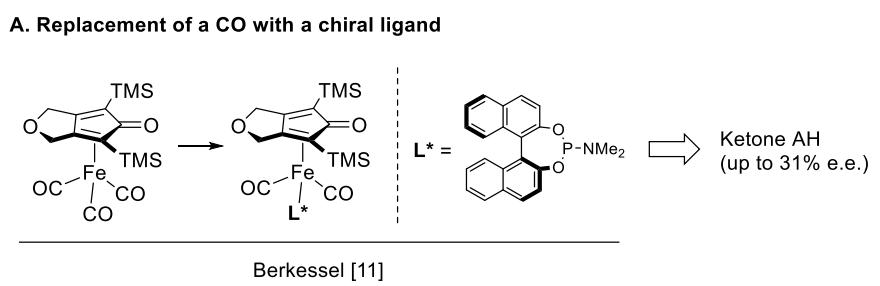

B. Use of a chiral cyclopentadienone ligand
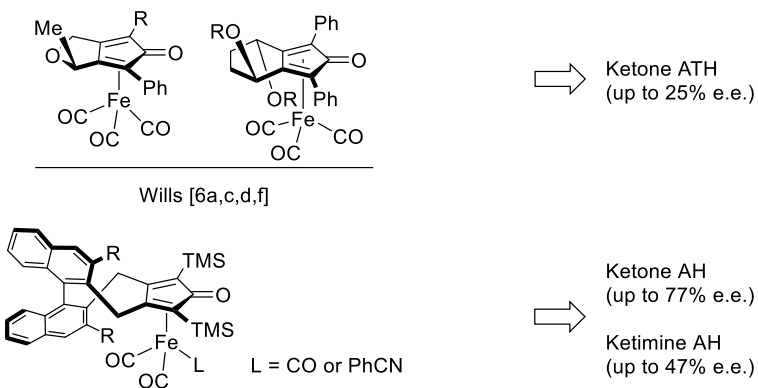

Our group $[4 a, e, f]$

C. This work: Formation of a stereogenic plane upon complexation of an achiral ligand
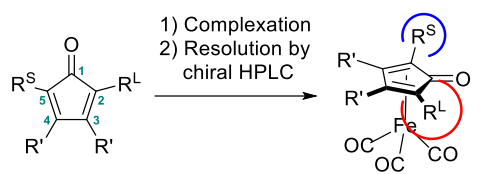

$\longrightarrow$ Ketone $\mathrm{AH}$

Fig. 1. Main strategies for synthesis of chiral (cyclopentadienone)iron complexes. $\mathrm{AH}=$ asymmetric hydrogenation; $\mathrm{ATH}=$ asymmetric transfer hydrogenation.

For the synthesis of chiral (cyclopentadienone)iron complexes, two main strategies have been employed so far: the first, developed by Berkessel and co-workers (Fig. 1 A), consists in replacing a CO ligand of an achiral complex with a chiral monodentate ligand [11]. The second, followed by Wills et al. [6a,c,d,f], by Ward/Renaud et al. [12] and by our research group $[4 \mathrm{a}, \mathrm{e}, \mathrm{f}]$, involves the use of a chiral cyclopentadienone ligand (Fig. 1 B) [13]. Attempts to merge these two approaches - i.e., introducing a chiral monodentate ligand into a chiral cyclopentadienone complex - did not lead to appreciable improvements in terms of enantioselectivity [2a,6c].

A third possible strategy, recently applied by Hayashi and coworkers to the synthesis of chiral Shvo-type ruthenium complexes [14], involves the use of achiral cyclopentadienones bearing different substituents on the two sides of the $\mathrm{C}=\mathrm{O}$ group to synthesize chiral complexes possessing a stereogenic plane (Fig. 1 C). This paper accounts for our efforts in this direction, with the synthesis of six new chiral iron complexes, two of which were resolved in the pure enantiomeric forms and tested in the asymmetric hydrogenation $(\mathrm{AH})$ of ketones and ketimines.

\section{Results and discussion}

2.1. Synthesis of the racemic complexes and test of their catalytic activity
In the ligand design, we decided to employ cyclopentadienone ligands featuring the biggest possible difference, in steric and/or stereoelectronic terms, between the substituents at C2 and C5. Indeed, in the commonly accepted TS of the reductions promoted by complexes 1 (Scheme $1 \mathrm{~B}$ ), the 2,5-substituents are relatively close to the approaching substrate.

We started with the preparation of complex $( \pm)-\mathbf{1 a}-$ featuring the same cyclopentadienone ligand as one of the Hayashi's Rucomplexes - by reacting $\mathrm{Fe}_{2}(\mathrm{CO})_{9}$ with the known cyclopentadienone 4 [14] (Scheme 2). The latter compound, in turn, was readily synthesized by condensation of benzil with 1phenyl-2-butanone (3), prepared as described in the literature $[14,15]$.
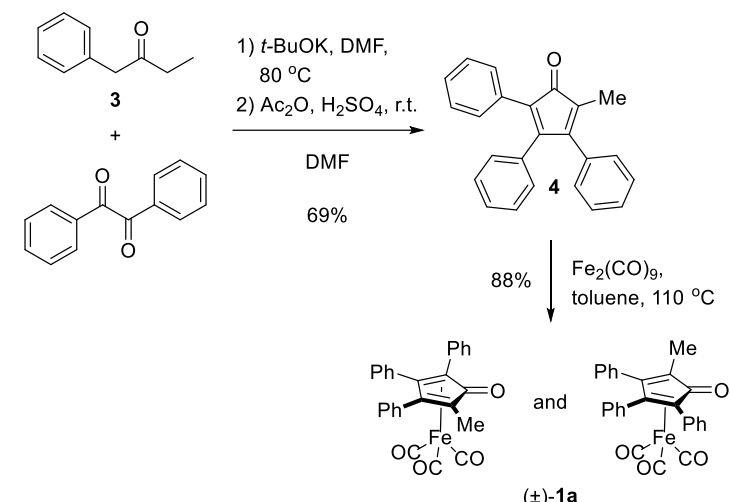

$( \pm)-1 \mathrm{a}$

Scheme 2. Synthesis of the racemic (cyclopentadienone)iron complex ( \pm )-1a

Next, starting from a common precursor (commercially available 1,7-octadiyne), we synthesized five racemic (cyclopentadienone)iron complexes featuring different substituents at C2 and C5 (Scheme 3). Following a literature procedure [16], 1,7-octadiyne was treated with LiHMDS and trimethylsilyl chloride to yield compound $\mathbf{5}$, bearing a trimethylsilyl (TMS) at one of its terminal alkyne groups. The remaining C-terminus was functionalized in two different ways: i) with a phenyl group (by Sonogashira coupling), yielding the asymmetric diyne 6 [17]; ii) with a methyl group, giving compound 7 [16]. The latter was either used directly for iron complexation or de-silylated with $\mathrm{K}_{2} \mathrm{CO}_{3}$ to yield diyne 8 [18], whose terminal alkyne group was functionalized with a triethylsilyl (TES) or a triisopropylsilyl (TIPS) or a trityl group yielding diynes $\mathbf{9 , 1 0}$ and 11, respectively. Treatment of diynes 67 and 9-11 with $\mathrm{Fe}_{2}(\mathrm{CO})_{9}$ in toluene at $110{ }^{\circ} \mathrm{C}$ gave the racemic complexes ( \pm )-1b-f in yields ranging from $13 \%$ to $60 \%$.

The catalytic activity of the newly synthesized complexes $( \pm)$ 1a-f, activated in situ with $\mathrm{Me}_{3} \mathrm{NO}$, in the hydrogenation of polar double bonds was tested using acetophenone (S1) and $(E)-N-(4-$ methoxyphenyl)-1-phenylethan-1-imine (S2) as model substrates (Table 1). Pre-catalysts $( \pm)-\mathbf{1 a}$ and $( \pm)-\mathbf{1 b}$ gave high conversion of S1 and S2 at both $5 \mathrm{~mol} \%$ and $2 \mathrm{~mol} \%$ loading (Table 1, entries 1-4). Along the series $( \pm)-\mathbf{1 c} \rightarrow( \pm)$-1f, conversions were found to decrease with the increasing size of the "large" substituent $\mathrm{R}^{\mathrm{L}}$ (Table 1, entries 5-12): while $( \pm)-\mathbf{1 c}\left(\mathrm{R}^{\mathrm{L}}=\mathrm{TMS}\right)$ and $( \pm)-\mathbf{1 d}\left(\mathrm{R}^{\mathrm{L}}=\mathrm{TES}\right)$ gave full conversion of $\mathbf{S} 1$ and acceptable conversions of $\mathbf{S 2}$ (entries 5-8), the activity of $( \pm)-\mathbf{1 e}\left(\mathrm{R}^{\mathrm{L}}=\right.$ TIPS) and $( \pm)-\mathbf{1 f}\left(\mathrm{R}^{\mathrm{L}}=\mathrm{CPh}_{3}\right)$ decreased dramatically (entries 9-12). Complex 1d features the largest possible $\mathrm{R}^{\mathrm{L}}$ compatible with an acceptable catalytic activity, and for this reason it was selected for enantiomer separation. Moreover, it was decided to resolve also complex 1a which, besides being the most active of the group, allows to establish a comparison with the corresponding ruthenium complex developed by Hayashi and co-workers [14]. 
A. Synthesis of the asymmetric diyne precursors

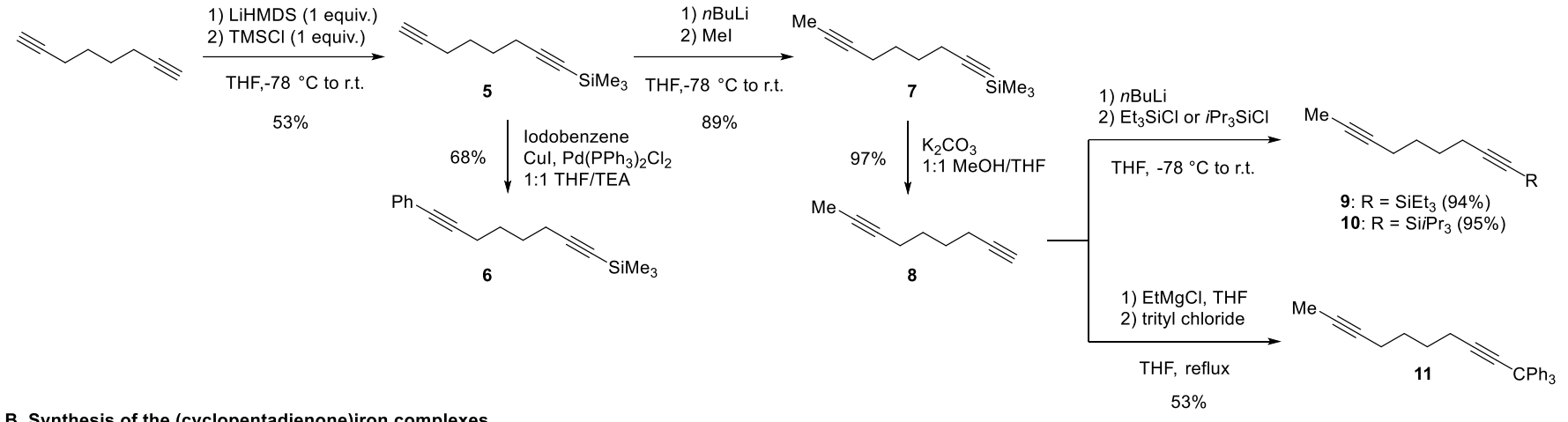

B. Synthesis of the (cyclopentadienone)iron complexes

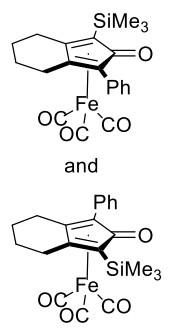

$( \pm)-1 \mathrm{~b}(60 \%)$

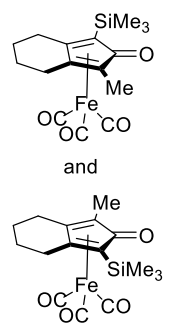

(土)-1c (20\%)

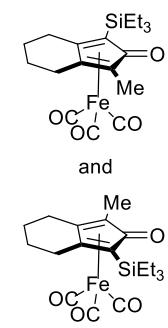

( \pm )-1d (25\%)

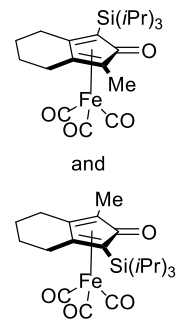

(士)-1e (13\%)

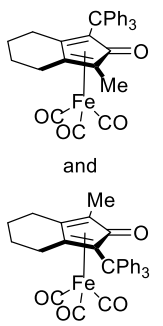

$( \pm)-1 f(33 \%)$

Scheme 3. A: Synthesis of the asymmetric diynes 5-11; B: Synthesis of the racemic (cyclopentadienone)iron complexes ( \pm )-1b-f.

\section{Table 1}

Test of the activity of the racemic complexes $( \pm)-\mathbf{1 a}-\mathbf{f}$ in $\mathrm{C}=\mathrm{O}$ and $\mathrm{C}=\mathrm{N}$ hydrogenation. ${ }^{a}$

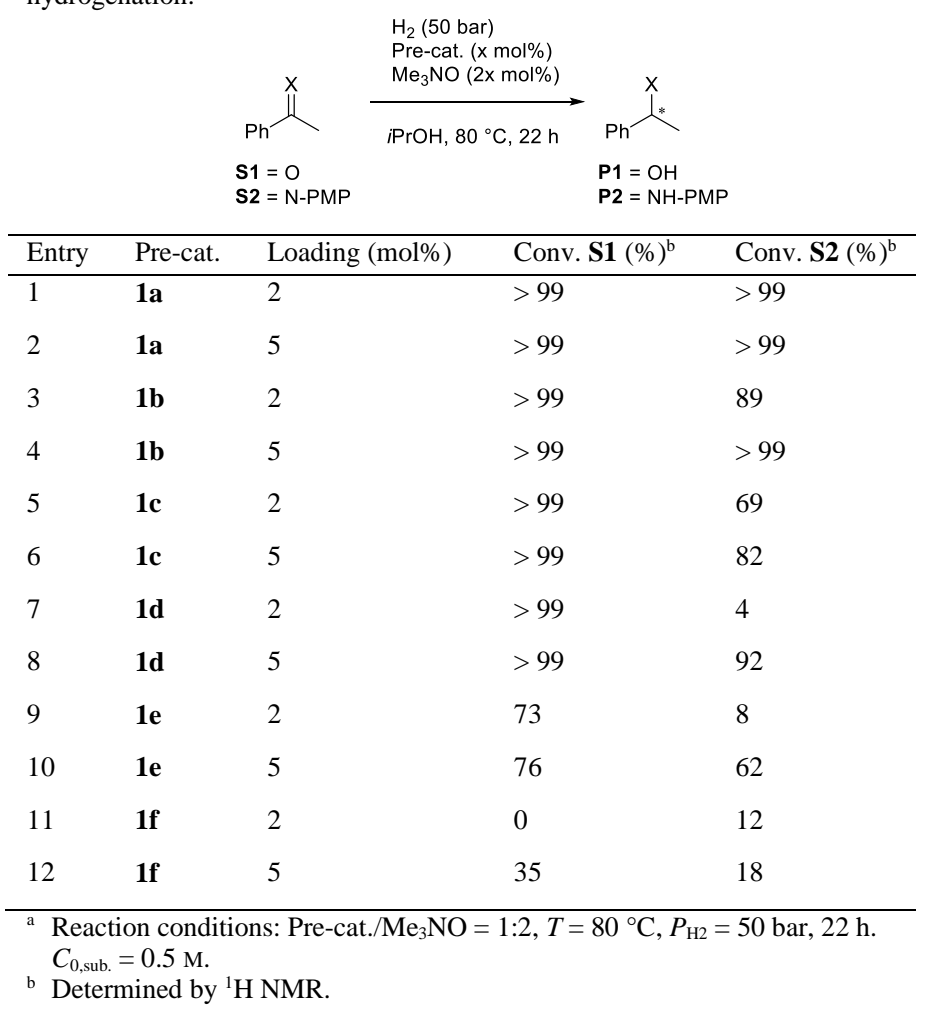

\subsection{Resolution of complexes $\mathbf{1 a}$ and $\mathbf{I d}$ by semipreparative} enantioselective HPLC and determination of the absolute configuration of the enantiomerically pure complexes

The racemic complexes $( \pm)-\mathbf{1 a}$ and $( \pm)$-1d were resolved by enantioselective HPLC. More in detail, the enantiomers of $( \pm)-\mathbf{1 a}$ were resolved on the $(R, R)$-DACH-DNB chiral stationary phase (CSP) under normal phase conditions (mobile phase: $n$ hexane/DCM 80:20 $+2 \% \mathrm{MeOH} v / v$ ), using both UV and ECD detection $\left(k^{\prime}{ }_{1}=2.36 ; \alpha=1.27 ; T=25^{\circ} \mathrm{C}\right.$, see Fig. $\left.2 \mathrm{~A}\right)$.

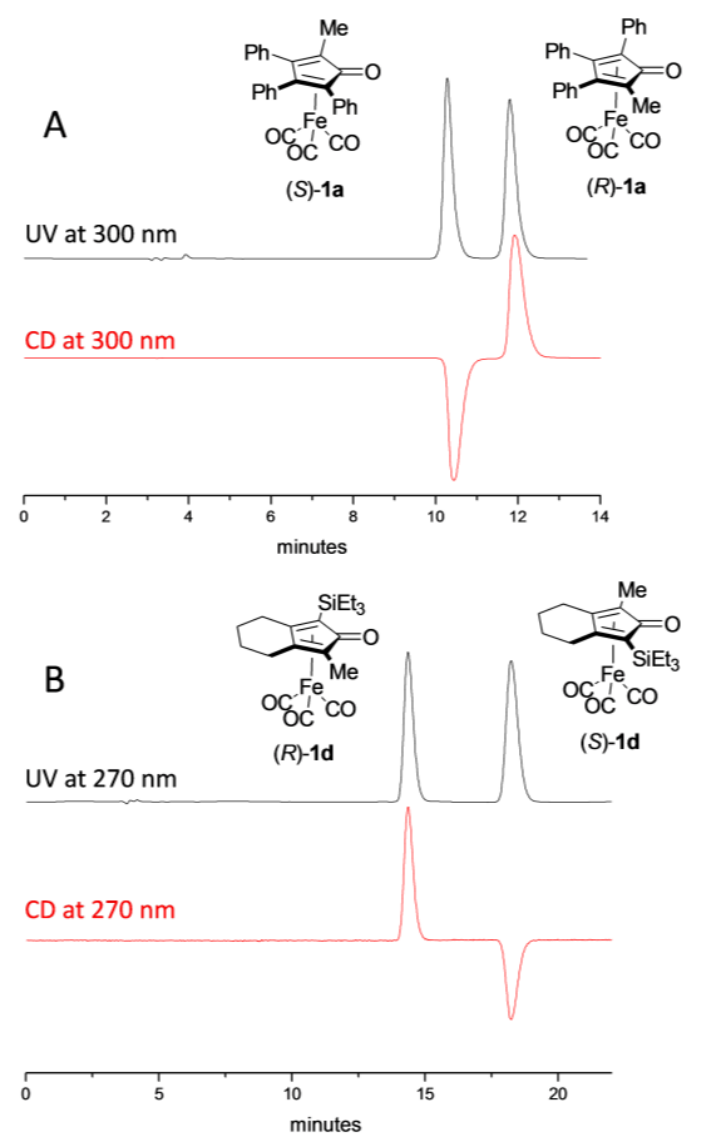

Fig. 2. Analytical separation of racemic mixtures ( \pm )-1a $(\mathrm{A})$ and $( \pm)-\mathbf{1 d}(\mathrm{B})$ by enantioselective HPLC. A) column: $(R, R)$-DACH-DNB $5 \mu \mathrm{m}(250 \mathrm{~mm} \times$ $4.6 \mathrm{~mm} \mathrm{L.} \times$ I.D.); eluent: $n$-hexane/DCM 80:20 $+2 \% \mathrm{MeOH} v / v$; flow rate $1.0 \mathrm{~mL} / \mathrm{min}$ at $25^{\circ} \mathrm{C}$. B $)$ column: Chiralpak IC $5 \mu \mathrm{m}(250 \mathrm{~mm} \times 4.6 \mathrm{~mm} \mathrm{L.x}$ I.D.); eluent: $n$-hexane/IPA 95:5 v/v; flow rate $1.0 \mathrm{~mL} / \mathrm{min}$ at $25^{\circ} \mathrm{C}$.

The separation was then scaled-up to semipreparative conditions, with 60 replicate separations $(2 \mathrm{mg}$ of sample injected in each run) carried out on a $1.0 \mathrm{~cm}$ internal diameter $(R, R)$-DACH-DNB column. This provided the two enantiomers with an overall 
recovery of $80 \%$. The e.e. values of the first and second eluted enantiomer - determined by analytical HPLC with UV and ECD detection at $300 \mathrm{~nm}$ - were $99 \%$ and $98 \%$, respectively (see the Supplementary data). As for complex $( \pm)-\mathbf{1 d}$, the enantiomers were separated on a Chiralpak IC CSP column (mobile phase: $n$ hexane/IPA 95:5 $v / v)$, achieving an $\alpha$ value of $1.37\left(k_{1}^{\prime}=2.84\right.$, Figure 2 B). In the semipreparative scale-up stage, each enantiomer $(70 \mathrm{mg}$, process yield $=79 \%$ ) was obtained with an enantiomeric excess of $99 \%$, measured by analytical HPLC with $\mathrm{UV}$ and CD detection at $270 \mathrm{~nm}$ (see the Supplementary data).

After the successful resolution of complexes 1a and 1d, we set to assign the absolute configuration (AC) of the separated enantiomers [19]. In the absence of configurationally known reference compounds which can be correlated to the chiral analyte, X-ray diffraction (XRD) analysis represents the firstchoice method for AC assignment [20]. Suitable crystals of the first-eluted enantiomer of complex 1a were obtained by vapor diffusion of pentane into a DCM solution of the complex, followed by cooling $\left(-18^{\circ} \mathrm{C}\right)$. Diffractometric analysis of a single crystal showed that the absolute configuration of this enantiomer, assigned according to the extended CIP rules [21], is $S$ (Fig. 3, additional details are reported in the Supplementary data).

As no crystals could be grown for the enantiomerically pure forms of complex $\mathbf{1 d}$, the AC was assigned by a spectroscopic/computational procedure [22 ]. The electronic circular dichroism (ECD) and optical rotation dispersion (ORD) spectra were registered for each of the separated enantiomers and compared to the equivalent spectra simulated by DFT calculations for the $R$ enantiomer (see details in Section 4.8). From inspection of the superimposed spectra (shown in Fig. 4), a good matching was found between the spectra of the first-eluted enantiomer and the calculated one. Thus, $R$ configuration was assigned to the first-eluted enantiomer of $\mathbf{1 d}$, and $S$ configuration to the second eluted one.
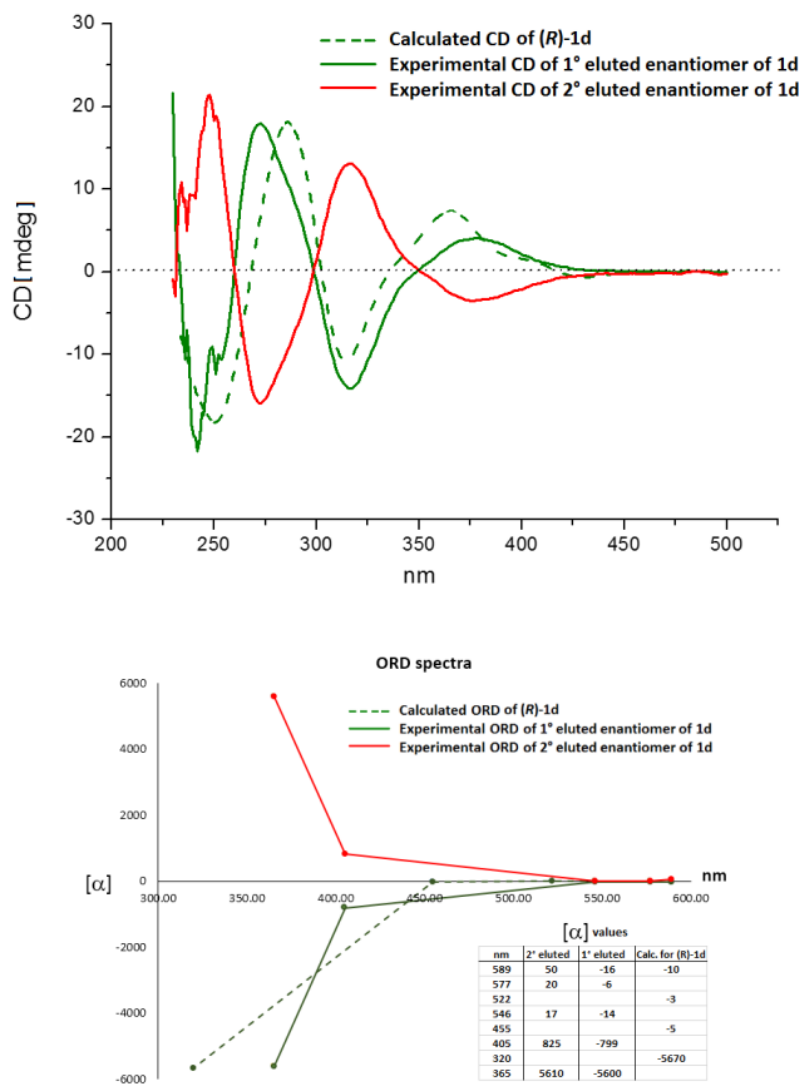

Fig. 4. ECD and ORD experimental spectra of the resolved enantiomers of $\mathbf{1 d}$ superimposed to the equivalent ones simulated through DFT calculations for the $R$ enantiomer.

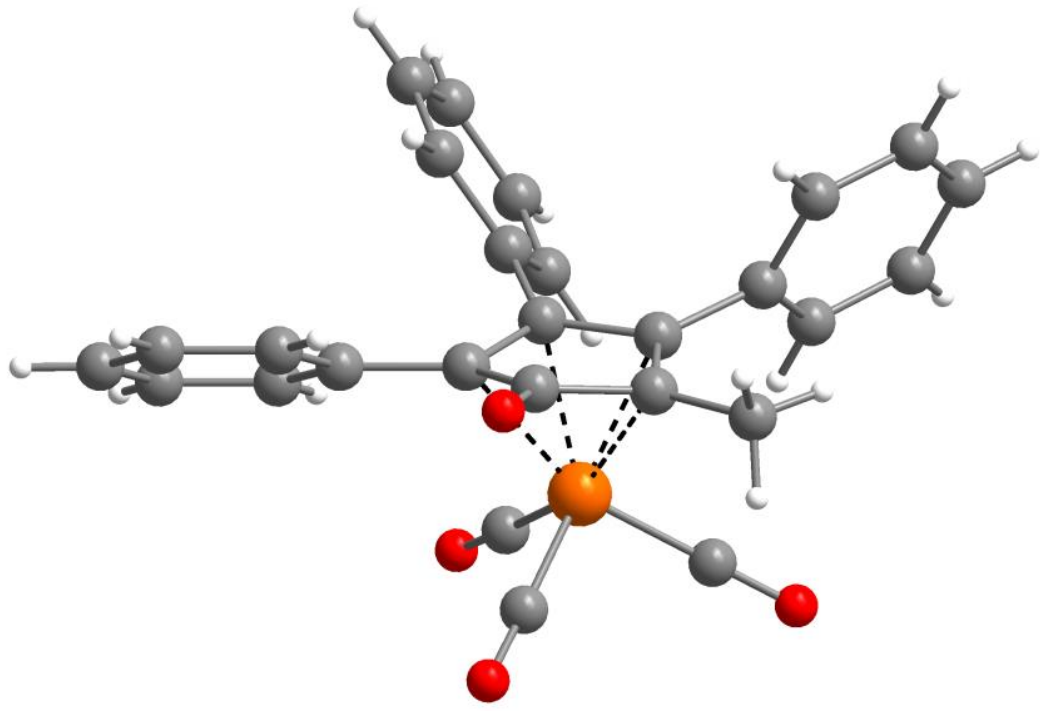

Fig 3. X-Ray crystal structure of the first-eluted enantiomer $(S)$ of complex 1a. Color codes: Fe, orange; O, red; C, gray; H, white. Selected bond distances: Fe$\mathrm{C} 1 \mathrm{~B}, 1.802(2)$; Fe-C1A, 1.804(2); Fe-C1C, 1.804(2); Fe-C4, 2.0721(16); Fe-C3, 2.0830(16); Fe-C5, 2.1222(18); Fe-C2, 2.1389(17).

\subsection{Test of the enantiomerically pure complexes in the AH of ketones and ketimines}

The enantiomerically pure complexes $(S)$-1a and $(R)$-1d were tested in the AH of several ketones, giving the results shown in Table 2. The complexes confirmed to be quite active precatalysts, giving always full conversion except in two cases [Table 2, entries 3 and 4 with pre-catalyst $(S)$-1a]. Unfortunately, only low enantioselectivity was obtained with substrates S1, S4, S5 and S6 (Table 2, entries 1, 3-5), whereas 2,2,2-trifluoro-1phenylethan-1-one $\mathbf{S 3}$ was reduced with moderate e.e. values (entry 2). Notably, the sense of stereoinduction was different with the two pre-catalysts, consistent with the assigned opposite configurations (see Section 2.2). 
Table 2

AH of ketones promoted by the chiral pre-catalysts $(S)-\mathbf{1 a}$ and $(R)-\mathbf{1 d}$. $^{\mathrm{a}}$
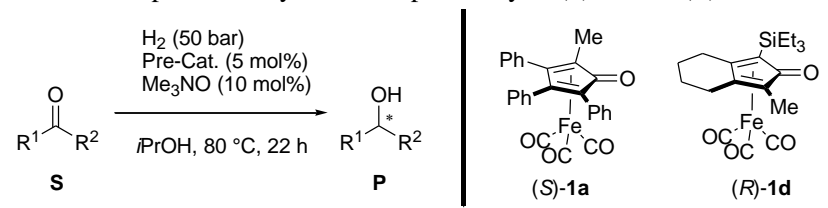

\begin{tabular}{|c|c|c|c|c|c|}
\hline \multirow[b]{2}{*}{ Entry } & \multirow[b]{2}{*}{ Substrate } & \multicolumn{2}{|c|}{ Pre-catalyst $(S)$-1a } & \multicolumn{2}{|c|}{ Pre-catalyst $(R)$-1d } \\
\hline & & Conv. $(\%)^{\mathrm{b}}$ & e.e. $(\%)^{\mathrm{b}}$ & Conv. $(\%)^{\mathrm{b}}$ & e.e. $(\%)^{\text {b }}$ \\
\hline $1^{c}$ & & $>99[99]^{\mathrm{d}}$ & $3, R$ & $>99[99]^{\mathrm{d}}$ & $9, R$ \\
\hline $2^{c}$ & & $>99[98]^{\mathrm{d}}$ & $45, R$ & $>99[98]^{\mathrm{d}}$ & $41, S$ \\
\hline $3^{c}$ & & $36[33]^{\mathrm{d}}$ & $9, S$ & $>99[99]^{\mathrm{d}}$ & $9, R$ \\
\hline $4^{c}$ & & $73[72]^{\mathrm{d}}$ & $13, S$ & $>99[99]^{\mathrm{d}}$ & $18, R$ \\
\hline $5^{e}$ & & $>99[85]^{\mathrm{d}}$ & $14, S$ & $>99[99]^{\mathrm{d}}$ & $18, S$ \\
\hline
\end{tabular}

a Reaction conditions: Substrate/Me $\mathrm{MNO}_{3} \mathrm{NPre}-\mathrm{cat} .=100: 10: 5, T=80^{\circ} \mathrm{C}, P_{\mathrm{H} 2}=$ 50 bar, 22 h. $C_{0, \text { sub. }}=0.5 \mathrm{M}$.

b Determined by GC analysis with a chiral capillary column.

c Absolute configuration of the product assigned by comparing the order of elution with literature data (see the experimental section).

d Isolated yield.

e Absolute configuration of the product assigned by comparing the sign of optical rotation with literature data (see the experimental section).

Table 3

AH of ketimines promoted by the chiral pre-catalysts $(S)-\mathbf{1 a}$ and $(R)-\mathbf{1 d} .^{\mathrm{a}}$

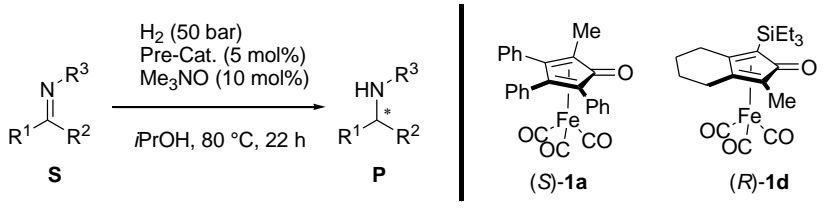

\begin{tabular}{|c|c|c|c|c|c|}
\hline \multirow[b]{2}{*}{ Entry } & \multirow[b]{2}{*}{ Substrate } & \multicolumn{2}{|c|}{ Pre-catalyst $(S)$-1a } & \multicolumn{2}{|c|}{ Pre-catalyst $(R)$-1d } \\
\hline & & Conv. $(\%)^{\mathrm{b}}$ & e.e. $(\%)^{\mathrm{c}}$ & Conv. $(\%)^{\mathrm{b}}$ & e.e. $(\%)^{\mathrm{c}}$ \\
\hline $1^{\mathrm{d}}$ & & $>99[98]^{\mathrm{e}}$ & $40, R$ & $96[96]^{\mathrm{e}}$ & $39, S$ \\
\hline $2^{f}$ & & $97[91]^{\mathrm{e}}$ & $29, R$ & $91[78]^{\mathrm{e}}$ & $6, S$ \\
\hline $3^{f}$ & & $>99[76]^{\mathrm{e}}$ & $54, R$ & $65[41]^{\mathrm{e}}$ & $40, S$ \\
\hline $4^{\mathrm{f}}$ & & $76[57]^{\mathrm{e}}$ & $18, S$ & $73[48]^{\mathrm{e}}$ & $6, R$ \\
\hline
\end{tabular}

\footnotetext{
Reaction conditions: Substrate/Me $\mathrm{Me}_{3} \mathrm{NO} /$ Pre-cat. $=100: 10: 5, \mathrm{~T}=80^{\circ} \mathrm{C}, P_{\mathrm{H} 2}=$ 50 bar, 22 h. $C_{0 \text { sub }}=0.5 \mathrm{M}$.

b Determined by ${ }^{1} \mathrm{H}$ NMR.

c Determined by enantioselective HPLC.

d Absolute configuration of the product assigned by comparing the sign of optical rotation with literature data (see the experimental section).

e Isolated yield.

f Absolute configuration assigned by comparing the order of elution with literature data (see the experimental section).
}

Complexes $(S)$-1a and $(R)$-1d were screened also in the $\mathrm{AH}$ of several $N$-PMP ketimines, showing again good activity: conversions were high $(>90 \%)$ in most cases, and reasonable in the remaining ones [Table 3 , entry 3 with $(R)-\mathbf{1 d}$ and entry 4 ]. Moderate e.e. values were achieved with the acetophenone- and the propiophenone-derived imines $\mathbf{S 2}$ and $\mathbf{S 8}$ (Table 3, entries 1 and 3), $(S)$-1a being slightly more enantioselective than $(R)-\mathbf{1 d}$. Imines S7 and S9 were hydrogenated with a low level of stereoselectivity, somewhat higher with $(S)$-1a than with $(R)-\mathbf{1 d}$ (Table 3, entries 2 and 4). With all ketimines, the two precatalysts showed opposite stereochemical preferences.

\section{Conclusion}

The work described in this paper aims at developing easy-toprepare chiral (cyclopentadienone)iron pre-catalysts for enantioselective reductions. Starting from readily accessible achiral materials, six chiral (cyclopentadienone)iron complexes (1a-f) possessing a stereogenic plane were synthesized in racemic form. To enhance the enantiodiscrimination, pre-catalyst were designed to maximize the difference - in terms of steric and stereoelectronic properties - between the substituents at position 2 and 5 of the cyclopentadienone ring (which are close to the substrate in the hydrogenation TS). Unfortunately, catalytic tests carried out with the racemic complexes $( \pm)$-1a-f revealed that the increasing the size of the 'large' substituent $\mathrm{R}^{\mathrm{L}}$ beyond a certain extent leads to a drop of catalytic activity. The best compromise between $\mathrm{R}^{\mathrm{L}}$ size and catalytic activity was reached with complexes 1a and 1d, which were resolved by semipreparative enantioselective HPLC. The absolute configuration of the two enantiomeric forms of complex 1a was assigned on the basis of XRD analysis of the first-eluted enantiomer $(S)$. For complex 1d, the assignment was made by comparing the ORD and ECD spectra of the two enantiomers with the equivalent spectra simulated by DFT calculations for the $R$ enantiomer. The enantiomerically pure complex $(S)$-1a promoted the $\mathrm{AH}$ of ketones and ketimines with low to moderate enantioselectivity, similar to that obtained with its ruthenium analog developed by Hayashi and co-workers [14]. To our surprise, the larger $\mathrm{R}^{\mathrm{L}}$ group present in pre-catalyst $(R)$-1d was not sufficient to enhance the enantiocontrol. Overall, these results confirm that an effective chiral (cyclopentadienone)iron pre-catalyst for enantioselctive reduction still represents a distant goal. However, we believe that the catalyst design adopted here, involving a short and straightforward synthetic route starting from cheap precursors, will provide useful directions for the future.

\section{Experimental Section}

\subsection{General information}

All reactions were carried out in flame-dried glassware with magnetic stirring under inert atmosphere (nitrogen or argon), unless otherwise stated. Solvents for reactions were distilled over the following drying agents and transferred under nitrogen: THF (Na), toluene (Na). Dry $N, N$-dimethylformamide (DMF, over molecular sieves in bottles with crown cap) was purchased from Sigma Aldrich and stored under nitrogen. All reagents were used without purification. Known compounds 3 [15], 4 [14], 5 [16], 6 [17], 7 [16] and 8 [18] were prepared following slightly modified literature procedures (see the Supplementary data). Imines S2 and S7-S9 were prepared as previously described [4a,b]. Reactions were monitored by analytical thin-layer chromatography (TLC) using silica gel 60 F254 pre-coated glass plates $(0.25 \mathrm{~mm}$ thickness). Visualization was accomplished by irradiation with a UV lamp and/or staining with a potassium permanganate alkaline solution. Flash Column Chromatography 
(FCC) was performed using silica gel (60 A, particle size 40-64 $\mu \mathrm{m})$ as stationary phase, following the procedure by Still and coworkers [23]. Optical rotations were measured with a Jasco-P2000 digital polarimeter at 20 or $22{ }^{\circ} \mathrm{C}$, and concentrations $(c)$ are given in $\mathrm{g} / 100 \mathrm{~mL} .{ }^{1} \mathrm{H}-\mathrm{NMR}$ spectra were recorded on a spectrometer operating at $400.13 \mathrm{MHz}$. Proton chemical shifts are reported in ppm $(\delta)$ with the solvent reference relative to tetramethylsilane (TMS) employed as the internal standard $\left(\mathrm{CDCl}_{3}, \delta=7.26 \mathrm{ppm} ; \mathrm{CD}_{2} \mathrm{Cl}_{2} \delta=5.32 \mathrm{ppm}\right)$. The following abbreviations are used to describe spin multiplicity: $\mathrm{s}=$ singlet, $\mathrm{d}$ $=$ doublet, $\mathrm{t}=$ triplet, $\mathrm{q}=$ quartet, $\mathrm{m}=$ multiplet. ${ }^{13} \mathrm{C}$-NMR spectra were recorded on a $400 \mathrm{MHz}$ spectrometer operating at 100.56 $\mathrm{MHz}$, with complete proton decoupling. Carbon chemical shifts are reported in $\mathrm{ppm}(\delta)$ relative to TMS with the respective solvent resonance as the internal standard $\left(\mathrm{CDCl}_{3} \delta=77.16 \mathrm{ppm}\right.$; $\left.\mathrm{CD}_{2} \mathrm{Cl}_{2} \delta=54.00 \mathrm{ppm}\right)$. The coupling constant values are given in $\mathrm{Hz}$. Infrared spectra were recorded on a standard FT/IR spectrometer. Melting points were recorded with a standard melting-point apparatus. High resolution mass spectra (HRMS) were performed on a ESI QTof SYNAPT G2 $\mathrm{Si}$ mass spectrometer (Waters), available at the UNITECH-COSPECT laboratories (Università degli Studi di Milano). Elemental analyses were performed on a Perkin Elmer Series II CHNS/O Analyzer 2000. X-ray intensity data were collected with a Bruker AXS APEXII CCD area detector by using graphite monochromated Mo-K $\alpha$ radiation.

\subsection{Complex ( \pm -1 $1 \boldsymbol{a}$}

In a Schlenk tube fitted with a Teflon-topped screw cap, $\mathrm{Fe}_{2}(\mathrm{CO})_{9}(1.1284 \mathrm{~g}, 3.102 \mathrm{mmol})$ was added to a stirred solution of cyclopentadienone $3(500 \mathrm{mg}, 1.551 \mathrm{mmol})$ in toluene (10 $\mathrm{mL}$ ). The reaction mixture was heated to $110^{\circ} \mathrm{C}$ and stirred for 16 hours. The reaction mixture was cooled down to room temperature and filtered through Celite (rinsing with AcOEt). After removal of the solvent, the residue was purified by flash column chromatograph $(9: 1$ hexane/AcOEt) to afford the product as a light yellow solid. Yield: $628 \mathrm{mg}(88 \%)$. M.p. $=199.1{ }^{\circ} \mathrm{C}$; ${ }^{1} \mathrm{H}-\mathrm{NMR}\left(400 \mathrm{MHz}, \mathrm{CD}_{2} \mathrm{Cl}_{2}\right) \delta$ 7.52-7.49 (m, 2H), 7.41-7.33 (m, $5 \mathrm{H})$, 7.28-7.23 (m, 4H), 7.16-7.15 (m, 4H), $1.94(\mathrm{~s}, 3 \mathrm{H}) ;{ }^{13} \mathrm{C}-$ NMR $\left(100 \mathrm{MHz}, \mathrm{CD}_{2} \mathrm{Cl}_{2}\right) \delta 209.52,171.68,132.28,132.02$, $131.93,130.96,130.66,130.49,129.39,129.18,128.79,128.55$, $128.49,128.44,128.33,105.35,104.93,83.63,80.60,10.81$; IR (film): $v=3058.6,2922.6,2855.1,2062.5,1991.1,1641.1$, 1577.5, 1499.4, 1445.4, 1390.4, 1171.5, 1073.2, 1029.8, 1003.8, $927.6,853.3,769.5,757.9,853.3,76935,757.9,736.7,698.1$, 666.3, 645.1, 613.3 $\mathrm{cm}^{-1}$; HRMS (ESI+): $\mathrm{m} / \mathrm{z} 463.0631[\mathrm{M}+\mathrm{H}]^{+}$ (calcd. for $\mathrm{C}_{32} \mathrm{H}_{27} \mathrm{FeO}_{4}$ : 463.0633).

\subsection{Triethyl(nona-1,7-diyn-1-yl)silane (9)}

$n \mathrm{BuLi}$ (1.6 $\mathrm{M}$ in hexanes, $2.29 \mathrm{~mL}, 3.661 \mathrm{mmol})$ was added dropwise to a stirred solution of diyne $\mathbf{8}(400 \mathrm{mg}, 3.328 \mathrm{mmol})$ in THF $(22 \mathrm{~mL})$ at $-78{ }^{\circ} \mathrm{C}$. After stirring for 1 hour at $-78{ }^{\circ} \mathrm{C}$, TES$\mathrm{Cl}(601.9 \mathrm{mg}, 3.9936 \mathrm{mmol})$ was added and the mixture was stirred at $-78{ }^{\circ} \mathrm{C}$ for $1 \mathrm{~h}$ before being allowed to warm to room temperature overnight. The reaction was quenched using saturated sat. aq. $\mathrm{NH}_{4} \mathrm{Cl}(25 \mathrm{~mL})$ and extracted with $\mathrm{Et}_{2} \mathrm{O}(3 \times 25$ $\mathrm{mL})$. The combined organic extracts were dried over $\mathrm{MgSO}_{4}$ and the solvent was removed in vacuo. The residue was purified by flash column chromatograph (98:2 hexane/AcOEt) to afford the pure product as a light yellow oil. Yield: $733 \mathrm{mg}(94 \%) .{ }^{1} \mathrm{H}-$ $\operatorname{NMR}\left(400 \mathrm{MHz}, \mathrm{CDCl}_{3}\right): 2.25(\mathrm{t}, J=6.80 \mathrm{~Hz}, 2 \mathrm{H}), 2.15-2.12$ $(\mathrm{m}, 2 \mathrm{H}), 1.76(\mathrm{t}, J=2.56 \mathrm{~Hz}, 3 \mathrm{H}), 1.61-1.57(\mathrm{~m}, 4 \mathrm{H}), 0.97(\mathrm{t}, J=$ $7.96 \mathrm{~Hz}, 9 \mathrm{H}), 0.59\left(\mathrm{q}, J_{1}=7.84 \mathrm{~Hz}, J_{2}=15.80 \mathrm{~Hz}, 6 \mathrm{H}\right) ;{ }^{13} \mathrm{C}-$ NMR $\left(100 \mathrm{MHz}, \mathrm{CDCl}_{3}\right): 108.38,81.80,78.92,75.77,28.18$, $27.99,19.57,18.37,7.58,4.69$, 3.55; IR (film): $v=3585.0$, 2953.5, 2916.8, 2874.4, 2733.6, 2172.4, 1655.6, 1458.9, 1414.5, $1377.9,1326.8,1260.3,1236.2,1096.3,1017.3,973.9,930.5$,
842.7, 806.1, 736.7, 726.1 $\mathrm{cm}^{-1}$; MS (ESI +) $\mathrm{m} / \mathrm{z} 257.51[\mathrm{M}+$ $\mathrm{Na}^{+}$(calcd. for $\mathrm{C}_{15} \mathrm{H}_{26} \mathrm{SiNa}$ : 257.17); elemental analysis (\%): $\mathrm{C}$ 75.60, H 11.01, (calcd. for $\mathrm{C}_{15} \mathrm{H}_{26}$ Si: C 76.84, H 11.18).

\subsection{Triisopropyl(nona-1,7-diyn-1-yl)silane (10)}

$n \operatorname{BuLi}(1.6 \mathrm{M}$ in hexanes, $2.29 \mathrm{~mL}, 3.661 \mathrm{mmol})$ was added dropwise to a stirred solution of diyne $8(400 \mathrm{mg}, 3.328 \mathrm{mmol})$ in THF $(22 \mathrm{~mL})$ at $-78{ }^{\circ} \mathrm{C}$. After stirring for 1 hour at $-78{ }^{\circ} \mathrm{C}$, TIPS$\mathrm{Cl}(770 \mathrm{mg}, 3.9936 \mathrm{mmol})$ was added and the mixture was stirred at $-78{ }^{\circ} \mathrm{C}$ for $1 \mathrm{~h}$ before being allowed to warm to room temperature overnight. The reaction was quenched using saturated sat. aq. $\mathrm{NH}_{4} \mathrm{Cl}(25 \mathrm{~mL})$ and extracted with $\mathrm{Et}_{2} \mathrm{O}(3 \times 25$ $\mathrm{mL}$ ). The combined organic extracts were dried over $\mathrm{MgSO}_{4}$ and the solvent was removed in vacuo. The residue was purified by flash column chromatograph (98:2 hexane/AcOEt) to afford the pure product as a light yellow oil. Yield: $1.167 \mathrm{~g}(95 \%) .{ }^{1} \mathrm{H}-$ NMR (400MHz, $\left.\mathrm{CDCl}_{3}\right): 2.28-2.24(\mathrm{~m}, 2 \mathrm{H}), 2.15-2.13(\mathrm{~m}, 2 \mathrm{H})$, $1.76(\mathrm{t}, J=2.60 \mathrm{~Hz} 3 \mathrm{H}), 1.62-1.60(\mathrm{~m}, 4 \mathrm{H}), 1.07-1.02(\mathrm{~m}, 21 \mathrm{H})$; ${ }^{13} \mathrm{C}-\mathrm{NMR}\left(100 \mathrm{MHz}, \mathrm{CDCl}_{3}\right): 108.89,80.41,78.92,75.75,28.13$, 28.06, 19.53, 18.75, 18.34, 11.45, 3.55; IR (film): $v=3584.1$, 2942.8, 2892.7, 2865.7, 2724.0, 2171.5, 1639.2, 1462.7, 1383.7, $1366.3,1326.8,1242.9,1071.3,1016.3,995.1,919.9,883.2$, 702.0, 676.9, 660.5, $621.0 \mathrm{~cm}^{-1}$; elemental analysis (\%): C 71.21, $\mathrm{H}$ 11.05, (calcd. for $\mathrm{C}_{18} \mathrm{H}_{32} \mathrm{Si}$ : C 78.18, $\mathrm{H}$ 11.66).

\subsection{Deca-2,8-diyne-1,1,1-triyltribenzene (11)}

In a Schlenk tube at $0{ }^{\circ} \mathrm{C}$, a solution of ethylmagnesium bromide ( $2 \mathrm{M}$ in THF, $4.1 \mathrm{~mL}, 8.33 \mathrm{mmol}$ ) was added dropwise to a stirred solution of compound $\mathbf{8}(1 \mathrm{~g}, 8.33 \mathrm{mmol})$ and THF (11 $\mathrm{mL}$ ). The resulting mixture was heated to reflux and stirred for 1 h. After cooling down to room temperature, trityl chloride $(2.322$ $\mathrm{g}, 8.33 \mathrm{mmol}$ ) was added. The resulting mixture was heated to reflux and stirred overnight. After cooling down to room temperature, the reaction was quenched with sat. aq. $\mathrm{NH}_{4} \mathrm{Cl}(15$ $\mathrm{mL})$, and the obtained aqueous phase was extracted with AcOEt $(3 \times 30 \mathrm{~mL})$. The organic layer was washed with water $(25 \mathrm{~mL})$ and brine $(25 \mathrm{~mL})$, dried over $\mathrm{Na}_{2} \mathrm{SO}_{4}$ and concentrated in vacuo. The crude product was purified by column chromatography on silica gel $(9: 1$ hexane/AcOEt) to give the product as a white solid. Yield: $1.61 \mathrm{~g}(53 \%)$. M.p. $=85.2{ }^{\circ} \mathrm{C} ;{ }^{1} \mathrm{H}-\mathrm{NMR}(400 \mathrm{MHz}$, $\left.\mathrm{CD}_{2} \mathrm{Cl}_{2}\right): 7.31-7.25(\mathrm{~m}, 15 \mathrm{H}), 2.41(\mathrm{t}, J=6.72 \mathrm{~Hz}, 2 \mathrm{H}), 2.20-2.15$ $(\mathrm{m}, 2 \mathrm{H}), 1.77(\mathrm{t}, J=2.56 \mathrm{~Hz}, 3 \mathrm{H}), 1.72-1.63(\mathrm{~m}, 4 \mathrm{H}) ;{ }^{13} \mathrm{C}-\mathrm{NMR}$ $\left(100 \mathrm{MHz}, \mathrm{CD}_{2} \mathrm{Cl}_{2}\right): 146.48,129.65,128.44,127.21,86.73$, $86.17,79.25,76.07,56.17,28.94,28.59,19.10,18.78,3.73$; IR (film): $v=3584.1,3083.6,3058.6,3021.9,2939.0,2859.0$, 1951.6, 1595.8, 1489.7, 1445.4, 1328.7, 1182.2, 1077.1, 1032.7, 1001.8, 891.0, 746.3, 689.1, 638.3, 618.1 $\mathrm{cm}^{-1}$; MS (ESI +) $\mathrm{m} / \mathrm{z}$ $363.52[\mathrm{M}+\mathrm{H}]^{+}$(calcd. for $\mathrm{C}_{28} \mathrm{H}_{26}$ : 363.52); elemental analysis (\%): C 92.77, $\mathrm{H}$ 7.22, (calcd. for $\mathrm{C}_{28} \mathrm{H}_{26}$ : C 92.77, H 7.23).

\subsection{General procedure for the synthesis of complexes $( \pm)-1 b-f$}

In a Schlenk tube fitted with a Teflon-topped screw cap, distilled toluene $(6 \mathrm{~mL})$ was added to a mixture of the diyne $(0.853 \mathrm{mmol})$ and $\mathrm{Fe}_{2}(\mathrm{CO})_{9}(621 \mathrm{mg}, 1.706 \mathrm{mmol})$. The mixture was heated to $110{ }^{\circ} \mathrm{C}$ and stirred overnight. After cooling down to room temperature, the products were purified by column chromatography (4:1 hexane/AcOEt) to afford the pure iron complexes.

\subsubsection{Complex ( \pm )-1b}

Prepared from diyne $\mathbf{6}$ according to the General procedure. Yield: $216 \mathrm{mg}$ (60\%). M.p. $=117.8{ }^{\circ} \mathrm{C}$; ${ }^{1} \mathrm{H}-\mathrm{NMR}(400 \mathrm{MHz}$, $\left.\mathrm{CD}_{2} \mathrm{Cl}_{2}\right)$ : 7.65-7.62 (m, 2H), 7.38-7.31 (m, 3H), 2.71-2.68 (m, $2 \mathrm{H}), 2.65-2.55(\mathrm{~m}, 2 \mathrm{H}), 1.91-1.84(\mathrm{~m}, 4 \mathrm{H}), 0.32(\mathrm{~s}, 9 \mathrm{H}) ;{ }^{13} \mathrm{C}-$ NMR (100 MHz, $\left.\mathrm{CD}_{2} \mathrm{Cl}_{2}\right)$ : 209.86, 175.84, 132.51, 130.19, $128.76,128.20,107.37,106.12,85.16,68.79,60.05,24.87$, 24.85, 22.88, 22.82, 0.01; IR (film): $v=2949.6,2852.2,2057.7$, 
1998.9, 1632.5, 1501.3, 1442.5, 1403.0, 1247.7, 1181.2, 1152.3, 1017.3, 892.0, 838.9, 757.9, 695.2, $617.1 \mathrm{~cm}^{-1}$; HRMS (ESI+): $m / z$, $423.0708[\mathrm{M}+\mathrm{H}]^{+}$(calcd. for $\mathrm{C}_{32} \mathrm{H}_{27} \mathrm{FeO}_{4}$ : 423.0715).

\subsubsection{Complex ( \pm )-1c}

Prepared from diyne 7 according to the General procedure. Yield: $61.4 \mathrm{mg}$ (25\%). M.p. $=74.4{ }^{\circ} \mathrm{C} ;{ }^{1} \mathrm{H}-\mathrm{NMR}(400 \mathrm{MHz}$, $\left.\mathrm{CD}_{2} \mathrm{Cl}_{2}\right): 2.57-2.43(\mathrm{~m}, 4 \mathrm{H}), 1.84-1.81(\mathrm{~m}, 4 \mathrm{H}), 1.68(\mathrm{~s}, 3 \mathrm{H}), 0.26$ (s, 9H); ${ }^{13} \mathrm{C}-\mathrm{NMR}\left(100 \mathrm{MHz}, \mathrm{CD}_{2} \mathrm{Cl}_{2}\right): 210.10,176.89,107.04$, 81.98, 68.47, 24.81, 23.07, 22.59, 22.43, 8.87, 0.04; IR (film): $v$ = 2950.6, 2056.7, 1996.0, 1635.3, 1447.3, 1247.7, 1087.7, 845.6, 761.7, 698.1, 654.7, 618.1 $\mathrm{cm}^{-1}$; HRMS (ESI+): $\mathrm{m} / \mathrm{z} 361.0552$ $[\mathrm{M}+\mathrm{H}]^{+}$(calcd. for $\mathrm{C}_{32} \mathrm{H}_{27} \mathrm{FeO}_{4}$ : 361.0559).

\subsubsection{Complex ( \pm )-1d}

Prepared from diyne 9 according to the General procedure. Yield: $90.7 \mathrm{mg}$ (25\%). M.p. $=58.5{ }^{\circ} \mathrm{C} ;{ }^{1} \mathrm{H}-\mathrm{NMR}(400 \mathrm{MHz}$, $\left.\mathrm{CD}_{2} \mathrm{Cl}_{2}\right): 2.52-2.47(\mathrm{~m}, 4 \mathrm{H}), 1.84-1.79(\mathrm{~m}, 4 \mathrm{H}), 1.64(\mathrm{~s}, 3 \mathrm{H}), 1.01$ $(\mathrm{t}, J=7.84 \mathrm{~Hz}, 9 \mathrm{H}), 0.88-0.81(\mathrm{~m}, 6 \mathrm{H}) ;{ }^{13} \mathrm{C}-\mathrm{NMR}(100 \mathrm{MHz}$, $\left.\mathrm{CD}_{2} \mathrm{Cl}_{2}\right): 210.10,176.82,107.28,107.17,82.08,67.19,25.36$, $23.15,22.54,22.43,8.91,7.91,4.36$; IR (film): $v=2951.5$, 2874.4, 2056.7, 1996.0, 1979.6, 1636.3, 1446.4, 1293.0, 1240.0, 1143.6, 1004.7, 784.9, 732.8, 699.1, $617.1 \mathrm{~cm}^{-1}$; HRMS (ESI+): calcd. for $\mathrm{C}_{19} \mathrm{H}_{27} \mathrm{FeO}_{4} \mathrm{Si}[\mathrm{M}+\mathrm{H}]$, found. HRMS (ESI+): $\mathrm{m} / \mathrm{z}$ $403.1018[\mathrm{M}+\mathrm{H}]^{+}$(calcd. for $\mathrm{C}_{32} \mathrm{H}_{27} \mathrm{FeO}_{4}$ : 403.1028).

\subsubsection{Complex ( \pm )-1e}

Prepared from diyne $\mathbf{1 0}$ according to the General procedure. Yield: $49.3 \mathrm{mg}$ (13\%). M.p. $=86.4{ }^{\circ} \mathrm{C}$; ${ }^{1} \mathrm{H}-\mathrm{NMR}(400 \mathrm{MHz}$, $\left.\mathrm{CD}_{2} \mathrm{Cl}_{2}\right): 2.60-2.52(\mathrm{~m}, 4 \mathrm{H}), 1.88-1.78(\mathrm{~m}, 4 \mathrm{H}), 1.64(\mathrm{~s}, 3 \mathrm{H})$, $1.49-1.41(\mathrm{~m}, 3 \mathrm{H}), 1.16(\mathrm{t}, J=7.88 \mathrm{~Hz}, 18 \mathrm{H}) ;{ }^{13} \mathrm{C}-\mathrm{NMR}(100$ $\left.\mathrm{MHz}, \mathrm{CD}_{2} \mathrm{Cl}_{2}\right)$ : 210.12, 176.55, 107.96, 106.46, 81.60, 69.92, $26.28,23.43,22.42,22.40,19.85,19.82,18.99,13.10,8.96$; IR (film): $v=2945.7,2865.7,2057.7,1997.9,1980.5,1632.5$, 1446.4, 1385.6, 1365.4, 1289.2, 1254.5, 1139.7, 1070.3, 1021.1, 881.3, 729.0, 687.5, 665.3, $618.1 \mathrm{~cm}^{-1}$; HRMS (ESI+): HRMS (ESI+): $m / z, 445.1493[\mathrm{M}+\mathrm{H}]^{+}$(calcd. for $\mathrm{C}_{32} \mathrm{H}_{27} \mathrm{FeO}_{4}$ : 445.1498).

\subsubsection{Complex ( \pm )- $1 f$}

Prepared from diyne $\mathbf{1 1}$ according to the General procedure. Yield: $149.3 \mathrm{mg}(33 \%)$. M.p. $=90.8{ }^{\circ} \mathrm{C} ;{ }^{1} \mathrm{H}-\mathrm{NMR}(400 \mathrm{MHz}$, $\left.\mathrm{CD}_{2} \mathrm{Cl}_{2}\right)$ : 7.25-7.16 (m, 15H), 2.60-2.51 (m, 2H), 1.81-1.70 (m, $2 \mathrm{H}), 1.63(\mathrm{~s}, 3 \mathrm{H}), 1.56-1.46(\mathrm{~m}, 2 \mathrm{H}), 1.30-1.19(\mathrm{~m}, 2 \mathrm{H}) ;{ }^{13} \mathrm{C}-$ NMR (100 MHz, $\left.\mathrm{CD}_{2} \mathrm{Cl}_{2}\right)$ : 210.39, 174.29, 146.61, 131.80, $127.83,127.10,104.03,101.74,95.58,78.84,60.61,24.21$, 23.75, 22.67, 21.86, 8.94; IR (film): $v=3057.6,2932.2,2054.8$, 1994.0, 1647.9, 1491.7, 1445.4, 1034.6, 854.3, 755.0, 736.7, 699.1, $613.3 \mathrm{~cm}^{-1}$; HRMS (ESI+): $\mathrm{m} / z, 531.1254[\mathrm{M}+\mathrm{H}]^{+}$(calcd. for $\mathrm{C}_{32} \mathrm{H}_{27} \mathrm{FeO}_{4}$ : 531.1259).

\subsection{Resolution of complexes 1 a and $1 \mathrm{~d}$ by chiral semipreparative HPLC and ECD spectra registration}

The analytical liquid chromatography was performed on an HPLC equipped with a Rheodyne model $7725 \mathrm{i} 20 \mu \mathrm{L}$ loop injector, a PU-1580-CO2 and PU-980 Jasco HPLC pumps, a UV detector Jasco-975, and a circular dichroism detector Jasco 995CD. Chromatographic data were collected and processed using Borwin software (Jasco Europe, Italy). The semipreparative liquid chromatography was performed on a Waters chromatograph (WatersAssociates) equipped with a $200 \mu \mathrm{L}$ loop injector, a UV SpectroMonitor 4100 spectrophotometer, and a refractive index detector. Racemic complex $( \pm)$-1a were resolved by semipreparative HPLC, using a $(R, R)$-DACH-DNB column $(250 \mathrm{~mm} \times 10 \mathrm{~mm} \mathrm{L.} \times$ I.D.), a mixture of $n$-hexane/DCM 80:20 $+2 \% \mathrm{MeOH} \mathrm{v} / \mathrm{v}$ was employed as eluent (flow rate $4.0 \mathrm{~mL} / \mathrm{min}$ and $\left.T_{\text {col. }}=25{ }^{\circ} \mathrm{C}\right)$. The sample of $( \pm)$-1a was dissolved in the mobile phase $(c=20 \mathrm{mg} / \mathrm{mL})$; each injection was $100 \mu \mathrm{L}$ (process yield 80\%). The enantiomeric excess, the UV, and ECD at $300 \mathrm{~nm}$ were determined by analytical HPLC with use of a Regis $(R, R)$-DACH-DNB column $(250 \mathrm{~mm} \times 4.6 \mathrm{~mm} \mathrm{~L}$. $\times$ I.D. $)$ under the same conditions employed for semipreparative HPLC, excepting the flow rate $(1.0 \mathrm{~mL} / \mathrm{min})$. Concerning the racemic $( \pm)-\mathbf{1 d}$, the enantiomers were resolved by using a Chiralpak IC column $(250 \mathrm{~mm} \times 10 \mathrm{~mm} \mathrm{~L} \times$ I.D. $)$ in semipreparative HPLC conditions, mobile phase consisted in a mixture of $n$-hexane/IPA 95:5 v/v (flow rate $5.0 \mathrm{~mL} / \mathrm{min}$ and $T_{\text {col. }}=25^{\circ} \mathrm{C}$ ). The racemic $( \pm)$-1d was dissolved in the mobile phase $(c=60 \mathrm{mg} / \mathrm{mL})$; each injection was $100 \mu \mathrm{L}$ (process yield 79\%). The enantiomeric excess, the UV, and ECD at $270 \mathrm{~nm}$ were determined by analytical HPLC with use of a Chiralpak IC column $(250 \mathrm{~mm} \times$ $4.6 \mathrm{~mm} \mathrm{~L} . \times$ I.D.) with a flow rate of $1.0 \mathrm{~mL} / \mathrm{min}$. The ECD spectra of chromatographically resolved $(R)-\mathbf{1 d}$ and $(S)$-1d were recorded with the circular dichroism detector Jasco J710 CD spectrometer, using $2.1 \times 10^{-5} \mathrm{M}$ solutions in $\mathrm{CHCl}_{3}$.

\subsubsection{Complex $(S)-1 a$ \\ $[\alpha]_{\mathrm{D}}^{22}=-20.82\left(c=0.061\right.$ in $\left.\mathrm{CHCl}_{3}\right)$. \\ 4.7.2. Complex $(R)$-1d \\ $[\alpha]_{\mathrm{D}}^{20}=-16.22\left(c=0.018\right.$ in $\left.\mathrm{CHCl}_{3}\right)$.}

\subsection{Single crystal XRD analysis of compound $(S)-1$ a}

$\mathrm{X}$-ray quality sample was selected at the optical microscope, resulting in pale-yellow prisms with dimensions of about $0.15 \times$ $0.10 \times 0.10 \mathrm{~mm}$. A crystal of $(S)$-1a, deriving from the first fraction obtained by enantiomer resolution by enantioselective HPLC, was mounted on a Bruker AXS APEXII CCD areadetector diffractometer, at room temperature, for the unit cell determination and data collection. Graphite-monochromatized $\operatorname{MoK} \alpha(\lambda=0.71073 \AA)$ radiation was used with the generator working at $50 \mathrm{kV}$ and $30 \mathrm{~mA}$. Orientation matrixes were initially obtained from least-squares refinement on ca. 300 reflections measured in three different $\omega$ regions, in the range $0^{\circ}<\theta<23^{\circ}$; cell parameters were optimized on the position, determined after integration, of ca. 7000 reflections. The intensity data were retrieved in the full sphere, within the $\theta$ limits reported in the crystal data section, from 1080 frames collected with a sample-detector distance fixed at $5.0 \mathrm{~cm}\left(50 \mathrm{~s}\right.$ frame $^{-1} ; \omega$ scan method, $\Delta \omega=0.5^{\circ}$ ). An empirical absorption correction was applied (SADABS) [24]. Crystal structure was solved by direct methods using SHELXT2017 and refined with SHELXL-2017/1 [25] within the Wingx suite of programs [26]. Hydrogen atoms were riding on their carbon atoms. Anisotropic temperature factors were assigned to all non-hydrogen atoms. Crystal data collection and refinement parameters are listed in the Supplementary data and in the cif files. An ORTEP [27] view of the molecules with the full numbering scheme is given in Fig. S1 and S2. Selected distances of bond lengths $(\AA)$ and angles $\left(^{\circ}\right)$ are given in Table $S 1$, while atomic coordinates and displacement parameters are listed in the corresponding cif file.

CCDC number 1885148 contains the full supplementary crystallographic data for this work. The latter can be obtained free of charge from the Cambridge Crystallographic Data Centre via www.ccdc.cam.ac.uk/data_request/cif. Crystal data for compound name: $\mathrm{C}_{27} \mathrm{H}_{18} \mathrm{FeO}_{4}, \mathrm{fW}=462.26 \mathrm{~g} \mathrm{~mol}^{-1}$, orthorhombic $\mathrm{P} 22_{1} 2_{1}$ (No. 19), $\mathrm{a}=9.1937(5), \mathrm{b}=12.5845(6)$ and $\mathrm{c}=$ 19.2348(10) $\AA ; \mathrm{V}=2225.4(2) \AA^{3} ; \mathrm{Z}=4 ; \mathrm{Mo}-\mathrm{K} \alpha \lambda=0.71073 \AA$; $\mathrm{T}(\mathrm{K}) 293(2) ; \rho_{\text {calc }}=1.38 \mathrm{~g} \mathrm{~cm}^{-3}, \mu(\mathrm{Mo}-\mathrm{K} \alpha)=0.708 \mathrm{~mm}^{-1} ; \theta$ range 1.934-31.685 ${ }^{\circ}$; Limiting indices $-13 \leq \mathrm{h} \leq 13,-18 \leq \mathrm{k} \leq 18$, $28 \leq 1 \leq 27$; data (unique), 6992 (6191); restraints, 0; parameters, 289; Goodness-of-Fit on $\mathrm{F}^{2}, 1.015 ; \mathrm{R}_{1}$ and $\mathrm{wR}_{2}(\mathrm{I}>2 \sigma(\mathrm{I})), 0.0279$ and $0.0676 ; \mathrm{R}_{1}$ and $\mathrm{wR}_{2}$ (all data), 0.0349 and 0.071; Flack parameter, 0.003(3); Largest Diff. Peak and Hole (e $\AA^{-3}$ ), 0.261 and -0.212 . 
4.9. Simulation of $O R D$ and $C D$ spectra for the $(R)$ enantiomer of $1 d$.

The chiroptical properties of the enantiomers of $\mathbf{1 d}$ were estimated by molecular modelling calculations performed in two steps. In the first step the structure of the $(R)$-1d enantiomer was optimized at the B3LYP/6-31G* level of theory using the computer program SPARTAN 10v1.1.0 (Wavefunction Inc., 18401 Von Karman Avenue, Suite 370, Irvine, CA 92612, USA). In the second step, by resorting to the Amsterdam Density Functional (ADF) package v. 2007.01, the optimized structure of $(R)$-1d was subjected to assessment of chiroptical properties, represented by the Optical Rotatory Dispersion (ORD) and the Electronic Circular Dichroism (ECD) spectra. Optical Rotation values $[\alpha]_{n}$ at four different wavelengths $n$, in the range 320-589 $\mathrm{nm}$, were assessed using the BLYP method, employing the QZ4P large core basis set, as implemented in ADF. Always starting from the same optimized $(R)-\mathbf{1 d}$ geometry, and again resorting to the ADF program, further calculations were also performed in order to simulate the relevant ECD spectrum. To this end, the set options were: single point calculation at the BLYP level of theory, employing the QZ4P large core basis set; 40 singlet and triplet excitations; diagonalization method: Davidson; velocity representation; scaling factor 1.00; peak width 31.0. It was found that, from comparison with the relevant experimental ECD and ORD spectra, the first-eluted enantiomer of 1d under the $\mathrm{CSP} /$ mobile phase conditions explored in the study had the $R$ configuration. As a consequence, $S$ configuration was assigned to the second-eluted enantiomer.

\subsection{General Procedure for the AH of ketones and ketimines}

Under argon atmosphere, the pre-catalyst was dispensed as DCM solution into oven-dried glass tubes fitted in an aluminum block inside a Schlenk tube. After removing DCM under vacuum, a $0.2 \mathrm{M}$ solution of $\mathrm{Me}_{3} \mathrm{NO}$ in $i \mathrm{PrOH}(0.1 \mathrm{~mL}, 0.002 \mathrm{mmol})$ was dispensed. The resulting mixture was stirred at room temperature for $20 \mathrm{~min}$, during which a deep orange color gradually developed. $i \mathrm{PrOH}(0.3 \mathrm{~mL})$ and the substrate $(0.2 \mathrm{mmol})$ were added in each vial. Each vial was capped with a Teflon septum pierced by a needle, the block was transferred into the autoclave, and stirring was started. After purging four times with hydrogen, the reaction was pressurized at 50 bar and heating was started $\left(80{ }^{\circ} \mathrm{C}\right)$. The reactions were stirred for $22 \mathrm{~h}$ under hydrogen pressure at $80{ }^{\circ} \mathrm{C}$. After cooling down to room temperature, the mixtures were filtered through a short part of celite and then analyzed for conversion and e.e. determination. When needed, product purification was carried out by flash column chromatography (hexane/AcOEt eluent mixtures).

\subsubsection{Analysis of ketone AH products}

The reaction mixtures were analyzed either by GC with a chiral column or by ${ }^{1} \mathrm{H}$ NMR / enantioselective HPLC to measure conversion and enantiomeric excess. Absolute configurations were determined by comparing the elution order with previous data obtained with the same column, unless otherwise stated.

\subsubsection{1-Phenylethanol (P1)}

Conversion and e.e. were determined by chiral GC [4e,f]. Capillary column: MEGA-DEX DAC Beta, diacetyl-tertbutylsilyl- $\beta$-cyclodextrin, $0.25 \mu \mathrm{m}$; diameter $=0.25 \mathrm{~mm}$; length $=$ $25 \mathrm{~m}$; carrier: hydrogen; inlet pressure: 1 bar; oven temperature: $95{ }^{\circ} \mathrm{C}$ for $20 \mathrm{~min}: t_{\text {substrate }}=4.76 \mathrm{~min} ; t_{R}=10.36 \mathrm{~min} ; t_{S}=12.39$ min.

4.10.1.2 2,2,2-Trifluoro-1-phenylethan-1-ol (P3) [14]
Conversion was determined by ${ }^{1} \mathrm{H}$ NMR, the product was purified by flash chromatography (hexane/ethyl acetate $=9 / 1$ ) and then analyzed by enantioselective HPLC [14].

HPLC conditions of e.e. determination: column: Chiralcel OD-H, $0.8 \mathrm{~mL} / \mathrm{min}, 95: 5$ hexane $/ \mathrm{PrOH}, \lambda=210 \mathrm{~nm}, t_{S}=12.7 \mathrm{~min}, t_{R}=$ $21.5 \mathrm{~min}$

GC conditions for determining conversion and e.e. were also established. Capillary column: MEGA-DEX DAC Beta, diacetyltert-butylsilyl- $\beta$-cyclodextrin, $0.25 \mu \mathrm{m}$; diameter $=0.25 \mu \mathrm{mm}$; length $=25 \mathrm{~m}$; carrier: hydrogen; inlet pressure: 1 bar; oven temperature: $100{ }^{\circ} \mathrm{C}$ for $20 \mathrm{~min}: t_{\text {substrate }}=1.38 \mathrm{~min} ; t_{S}=8.97 \mathrm{~min}$, $t_{R}=10.23 \mathrm{~min}$;

\subsubsection{1-Phenylpropan-1-ol (P4)}

Conversion and e.e. were determined by chiral GC [4e,f]. Capillary column: MEGA-DEX DAC Beta, diacetyl-tertbutylsilyl- $\beta$-cyclodextrin, $0.25 \mu \mathrm{m}$; diameter $=0.25 \mathrm{~mm}$; length $=$ $25 \mathrm{~m}$; carrier: hydrogen; inlet pressure: 1 bar; oven temperature: $120{ }^{\circ} \mathrm{C}$ for $15 \mathrm{~min}: t_{\text {substrate }}=2.91 \mathrm{~min} ; t_{R}=3.45 \mathrm{~min} ; t_{S}=3.58$ min.

\subsubsection{1-(Naphthalen-2-yl)ethan-1-one (P5)}

Conversion and e.e. were determined by chiral GC [4e,f]. Capillary column: MEGA-DEX DAC Beta, diacetyl-tertbutylsilyl- $\beta$-cyclodextrin, $0.25 \mu \mathrm{m}$; diameter $=0.25 \mathrm{~mm}$; length $=$ $25 \mathrm{~m}$; carrier: hydrogen; inlet pressure: 1 bar; oven temperature: $150{ }^{\circ} \mathrm{C}$ for $20 \mathrm{~min}: t_{\text {substrate }}=9.23 \mathrm{~min} ; t_{R}=14.89 \mathrm{~min} ; t_{S}=16.07$ $\min$.

\subsubsection{3,4-Dihydronaphthalen-2(1H)-one (P6)}

Conversion and e.e. were determined by chiral GC. Capillary column: MEGA-DEX DAC Beta, diacetyl-tert-butylsilyl- $\beta$ cyclodextrin, $0.25 \mu \mathrm{m}$; diameter $=0.25 \mathrm{~mm}$; length $=25 \mathrm{~m}$; carrier: hydrogen; inlet pressure: 1 bar; oven temperature: $110{ }^{\circ} \mathrm{C}$ for 40 min: $t_{R}=18.74 \mathrm{~min} ; t_{S}=19.43 \mathrm{~min} ; t_{\text {substrate }}=26.03 \mathrm{~min}$. Absolute configurations were assigned by comparing the sign of optical rotation with literature data $\left([\alpha]_{\mathrm{D}}{ }^{23}=-51.4, c 0.70\right.$ in $\mathrm{CHCl}_{3}, 82 \%$ e.e., $S$ ) [28].

\subsubsection{Analysis of ketimine AH products}

Conversions were determined by ${ }^{1} \mathrm{H}$ NMR analysis of the crude reaction mixtures. After purification by flash chromatography (hexane/ethyl acetate/triethylamine, 89.6/10/0.4), the enantiomeric excesses were determined by HPLC analysis with a chiral column.

\subsubsection{4-Methoxy-N-(1-phenylethyl)aniline (P2) [4b]}

Column: Chiralpak AD-H, $0.8 \mathrm{~mL} / \mathrm{min}, 97: 3$ hexane $/ \mathrm{iPrOH}, \lambda$ $=210 \mathrm{~nm}, t_{R}=11.79 \mathrm{~min}, t_{S}=13.40 \mathrm{~min}$. Absolute configuration was determined by comparison of the sign of optical rotation with literature data $\left([\alpha]_{\mathrm{D}}{ }^{15}=+8.5, c 0.9\right.$ in $\mathrm{CHCl}_{3}, 98 \%$ e.e., $\left.R\right)$ [29].

4.10.2.2 4-Methoxy-N-(1-(naphthalen-2-yl)ethyl)aniline (P7) [4b] Column: Chiralcel OD-H, $0.5 \mathrm{~mL} / \mathrm{min}, 9: 1$ hexane $/ \mathrm{PrOH}, \lambda=$ $210 \mathrm{~nm}, t_{R}=15.70 \mathrm{~min}, t_{S}=17.73 \mathrm{~min}$. Absolute configuration was determined by comparing the elution order with previous data obtained with the same column [29a].

\subsubsection{4-Methoxy-N-(1-phenylpropyl)aniline (P8) [4b]}

Column: Chiralcel OD-H, $0.8 \mathrm{~mL} / \mathrm{min}, 98: 2$ hexane $/ \mathrm{PrOH}, \lambda$ $=210 \mathrm{~nm}, t_{R}=10.66 \mathrm{~min}, t_{S}=11.90 \mathrm{~min}$. Absolute configuration was determined by comparing the elution order with previous data obtained with the same column [29a].

\subsubsection{4-Methoxy-N-(octan-2-yl)aniline (P9) [4b]}

Column: Phenomenex Cellulose $3(5 \mu \mathrm{m}), 0.5 \mathrm{~mL} / \mathrm{min}, 100: 1$ hexane $/ \mathrm{PrOH}, \lambda=210 \mathrm{~nm}, t_{R}=14.93 \mathrm{~min}, t_{S}=15.57 \mathrm{~min}$. 
Absolute configuration was determined by comparing the elution order with previous data obtained with the same column [29a].

\section{Acknowledgments}

X. Bai thanks the China Scholarship Council for a $\mathrm{PhD}$ fellowship (CSC No. 201608410107). L. Pignataro thanks the Dipartimento di Chimica, Università degli Studi di Milano, for financial support (Piano di Sostegno alla Ricerca 2015-2017). We thank Prof. F. Gasparrini of "Sapienza" Università di Roma for inspiring discussions and Mr. Andrea Dell'Acqua for experimental assistance.

\section{Supplementary material}

Supplementary data associated with this article can be found, in the online version, at https://doi.org/10.1016/j.tet.2019.01.057.

\section{References}

[1] For reviews on homogeneous iron catalysis, see:

(a) I. Bauer, H.-J. Knölker, Chem. Rev. 115 (2015) 3170-3387;

(b) K. Gopalaiah, Chem. Rev. 113 (2013) 3248-3296;

(c) M. Darwish, M. Wills, Catal. Sci. Technol. 2 (2012) 243-255;

(d) W.M. Czaplik, M. Mayer, J. Cvengroš, A. Jacobi von Wangelin, ChemSusChem 2 (2009) 396-417;

(e) S. Enthaler, K. Junge, M. Beller, Angew. Chem. Int. Ed. 47 (2008) 3317-3321;

(f) C. Bolm, J. Legros, J. Le Paih, L. Zani, Chem. Rev. 104 (2004) 6217-6254.

[2] For reviews on catalytic applications of (cyclopentadienone)iron complexes, see:

(a) U. Piarulli, S. Vailati Facchini, L. Pignataro, Chimia 71 (2017) 580-585;

(b) A. Quintard, J. Rodriguez, Angew. Chem. Int. Ed. 53 (2014), 4044-4055.

[3] For catalytic use of (hydroxycyclopentadienyl)iron complexes (2) in isolated form, see:

(a) O. El-Sepelgy, N. Alandini, M. Rueping, Angew. Chem. Int. Ed. 55 (2016) 13602-13605;

(b) H.-J. Pan, T.W. Ng, Y. Zhao, Org. Biomol. Chem. 14 (2016) 5490-5493;

(c) H.-J. Pan, T.W. Ng, Y. Zhao, Chem. Commun. 51 (2015) 11907-11910;

(d) S. Zhou, S. Fleischer, H. Jiao, K. Junge, M. Beller, Adv. Synth. Catal. 356 (2014) 3451-3455;

(e) S. Fleischer, S. Zhou, S. Werkmeister, K. Junge, M. Beller, Chem. Eur. J. 19 (2013) 4997-5003;

(f) S. Fleischer, S. Werkmeister, S. Zhou, K. Junge, M. Beller, Chem. Eur. J. 18 (2012) 9005-9010;

(g) S. Zhou, S. Fleischer, K. Junge, M. Beller, Angew. Chem. Int. Ed. 50 (2011) 5120-5124;

(h) M.G. Coleman, A.N. Brown, B.A. Bolton, H. Guan, Adv. Synth. Catal. 352 (2010) 967-970;

(i) C.P. Casey, H. Guan, J. Am. Chem. Soc. 131 (2009) 24992507;

(j) C.P. Casey, H. Guan, J. Am. Chem. Soc. 129 (2007) 58165817.

[4] For recent contributions by our research group on catalytic applications of (cyclopentadienone)iron complexes, see:

(a) M. Cettolin, X. Bai, D. Lübken, M. Gatti, S. Vailati Facchini, U. Piarulli, L. Pignataro, C. Gennari, Eur. J. Org. Chem. (2018) DOI: 10.1002/ejoc.201801348;

(b) S. Vailati Facchini, M. Cettolin, X. Bai, G. Casamassima, L. Pignataro, C. Gennari, U. Piarulli, Adv. Synth. Catal. 360 (2018) 1054-1059;

(c) S. Vailati Facchini, J.-M. Neudörfl, L. Pignataro, M. Cettolin, C. Gennari, A. Berkessel, U. Piarulli, ChemCatChem 9 (2017) 1461-1468;

(d) P. Gajewski, A. Gonzalez-de-Castro, M. Renom-Carrasco, U. Piarulli, C. Gennari, J.G. de Vries, L. Lefort, L. Pignataro, ChemCatChem 8 (2016) 3431-3435; (e) P. Gajewski, M. Renom-Carrasco, S. Vailati Facchini, L. Pignataro, L. Lefort, J.G. de Vries, R. Ferraccioli, U. Piarulli, C. Gennari, Eur. J. Org. Chem. (2015) 5526-5536;

(f) P. Gajewski, M. Renom-Carrasco, S. Vailati Facchini, L. Pignataro, L. Lefort, J.G. de Vries, R. Ferraccioli, A. Forni, U. Piarulli, C. Gennari, Eur. J. Org. Chem. (2015) 1887-1893.

[5] (a) A. Lator, S. Gaillard, A. Poater, J.-L. Renaud, Chem. Eur. J. 24 (2018) 5770-5774;

(b) D. Brenna, S. Rossi, F. Cozzi, M. Benaglia, Org. Biomol. Chem. 15 (2017) 5685-5688;

(c) T.-T. Thai, D. S. Mérel, A. Poater, S. Gaillard, J.-L. Renaud, Chem. Eur. J. 21 (2015) 7066-7070;

(d) S. Moulin, H. Dentel, A. Pagnoux-Ozherelyeva, S. Gaillard, A. Poater, L. Cavallo, J.-F. Lohier, J.-L. Renaud, Chem. Eur. J. 19 (2013) 17881-17890;

(e) D. S. Mérel, M. Elie, J.-F. Lohier, S. Gaillard, J.-L. Renaud, ChemCatChem 5 (2013) 2939-2945;

(f) S. Fleischer, S. Zhou, K. Junge, M. Beller, Angew. Chem. Int. Ed. 52 (2013) 5120-5124;

g) A. Pagnoux-Ozherelyeva, N. Pannetier, M.D. Mbaye, S. Gaillard, J.-L. Renaud, Angew. Chem. Int. Ed. 51 (2012) 49764980;

(h) A. Tlili, J. Schranck, H. Neumann, M. Beller, Chem. Eur. J. 18 (2012) 15935-15939;

(i) A. Berkessel, S. Reichau, A. von der Höh, N. Leconte, J.-M. Neudörfl, Organometallics 30 (2011) 3880-3887.

[6] (a) A. Del Grosso, A.E. Chamberlain, G.J. Clarkson, M. Wills, Dalton Trans. 47 (2018) 1451-1470;

(b) T.W. Funk, A.R. Mahoney, R. A. Sponenburg, K.P. Zimmerman, D.K. Kim, E.E. Harrison, Organometallics 37 (2018) 1133-1140;

(c) R. Hodgkinson, A. Del Grosso, G. Clarkson, M. Wills, Dalton Trans. 45 (2016) 3992-4005;

(d) J.P. Hopewell, J.E.D. Martins, T.C. Johnson, J. Godfrey, M. Wills, Org. Biomol. Chem. 10 (2012) 134-145;

(e) T.N. Plank, J.L. Drake, D.K. Kim, T.W. Funk, Adv. Synth. Catal. 354 (2012) 597-601;

(f) T.C. Johnson, G.J. Clarkson, M. Wills, Organometallics 30 (2011) 1859-1868.

[7] S.A. Moyer, T.W. Funk, Tetrahedron Lett. 51 (2010) 5430-5433.

[8] (a) A. Lator, S. Gaillard, A. Poater, J.-L. Renaud, Org. Lett. 20 (2018) 5985-5990;

(b) K. Polidano, B.D.W. Allen, J.M.J. Williams, L.C. Morrill, ACS Catal. 8 (2018) 6440-6445;

(c) T. Yan, B.L. Feringa, K. Barta, Sci. Adv. 3 (2017) eaao6494

(d) M. Vayer, S.P. Morcillo, J. Dupont, V. Gandon, C. Bour, Angew. Chem. Int. Ed. 57 (2018) 3228-3232;

(e) T.J. Brown, M. Cumbes, L.J. Diorazio, G.J. Clarkson, M. Wills, J. Org. Chem. 82 (2017) 10489-10503;

(f) T. Yan, B.L. Feringa, K. Barta, ACS Catal. 6 (2016) 381-388; (g) A. Quintard, J. Rodriguez, ChemSusChem 9 (2016) 28-30;

(h) A. J. Rawlings, L.J. Diorazio, M. Wills, Org. Lett. 17 (2015) 1086-1089;

(i) H.-J. Pan, T.W. Ng, Y. Zhao, Chem. Commun. 51 (2015) 11907-11910;

(j) T. Yan, B. L. Feringa, K. Barta, Nat. Commun. 5 (2014) 5602.

[9] (a) S. Elangovan, J.-B. Sortais, M. Beller, C. Darcel, Angew. Chem. Int. Ed. 54 (2015) 14483-14486;

(b) M. Roudier, T. Constantieux, A. Quintard, J. Rodriguez, Org. Lett. 16 (2014) 2802-2805;

(c) A. Quintard, T. Constantieux, J. Rodriguez, Angew. Chem. Int. Ed. 52 (2013) 12883-12887.

[10] (a) A. Guđmundsson, K.P.J. Gustafson, B.K. Mai, B. Yang, F. Himo, J.-E. Bäckvall, ACS Catal. 8 (2018) 12-16;

(b) O. El-Sepelgy, A. Brzozowska, J. Sklyaruk, Y.K. Jang, V. Zubar, M. Rueping, Org. Lett. 20 (2018) 696-699;

(c) O. El-Sepelgy, A. Brzozowska, L.M. Azofra, Y.K. Jang, L. Cavallo, M. Rueping, Angew. Chem. Int. Ed. 56 (2017) 1486314867.

[11] A. Berkessel, S. Reichau, A. von der Höh, N. Leconte, J.-M. Neudörfl, Organometallics 30 (2011) 3880-3887.

[12] Chiral biotinylated complexes were prepared and then incorporated within streptavidin to afford 'artificial iron 
hydrogenases', see: D.S. Mérel, S. Gaillard, T.R. Ward, J.-L. Renaud, Catalysis Letters 146 (2016) 564-569.

[13] This strategy had been already employed in the synthesis of chiral (cyclopentadienone)ruthenium complexes, see: Y. Yamamoto, K. Yamashita, M. Nakamura, Organometallics 29 (2010) 1472-1478.

[14] X. Dou, T. Hayashi, Adv. Synth. Catal. 358 (2016) 1054-1058.

[15] T.V. Chciuk, W.R. Anderson, R.A. Flowers II, Organometallics 36 (2017) 4579-4583.

[16] L. Hoffmeister, T. Fukuda, G. Pototschnig, A. Fürstner, Chem. Eur. J. 21 (2015) 4529-4533.

[17] S. Kolodych, O. Koniev, Z. Baatarkhuu, J.Y. Bonnefoy, F. Debaene, S. Cianférani, A.V. Dorsselaer, A. Wagner, Bioconjugate Chem. 26 (2015) 197-200.

[18] D. Listunov, C. Billot, E. Joly, I. Fabing, Y. Volovenko, Y. Génisson, V. Maraval, R. Chauvin, Tetrahedron 71 (2015) 79207930.

[19] Assigning the configuration of chiral metal complexes is often a non-trivial task due to the articulated relationship existing between 3D-geometry and the electronic configuration of transition metals located in a chiral environment. Indeed, involvement of d-type orbitals and higher angular momentum orbital, sometimes spinpolarized, must be considered. All these aspects make the theoretical description of the metal-ligand interactions more intricate compared to that of chiral organic molecules, which only involves $\mathrm{s}$ and $\mathrm{p}$ orbitals. For a recent review on this topic, see: $\mathrm{T}$. $\mathrm{Wu}$, X.Z. You, P. Bouř, Coord. Chem. Rev. 284 (2015) 1-18.

[20] (a) H.-D. Flack, G. Bernardinelli, Chirality 20 (2008) 681-690;

(b) S. Parsons, Tetrahedron:Asymmetry 28 (2017) 1304-1313.

[21] (a) J.-P. Djukic, A. Hijazi, H.D. Flack, G. Bernardinelli, Chem. Soc. Rev. 37 (2008) 406-425;

(b) T.E. Sloan, Top. Stereochem.12 (1981) 1-36;

(c) K. Schlögl, Top. Stereochem.1 (1967) 39-91;

(d) R.S. Cahn, C. Ingold, V. Prelog, Angew. Chem. Int. Ed. Engl. 5 (1966) 385-415.

[22] In the first step, the enantiomerically pure sample is submitted to spectroscopic measurements based on chiroptical methods, such as electronic circular dichroism (ECD), vibrational circular dichroism (VCD), or optical rotation (OR). In the second step, the spectra acquired are compared to the corresponding spectra simulated by quantum chemical calculations for the structure of one or more of the possible stereoisomers. A good match between the compared spectra then provides the absolute configuration, see: S. Superchi, P. Scafato, M. Gorecki, G. Pescitelli, Curr. Med. Chem. 25 (2018) 287-320.

[23] W.C. Still, M. Kahn, A. Mitra, J. Org. Chem. 43 (1978) 29232925.

[24] G.M. Sheldrick, SADABS, Program for Absorption Correction; University of Göttingen, Göttingen, Germany, 1996.

[25] (a) G.M. Sheldrick, Acta Crystallogr. A 64 (2008) 112-122; (b) G.M. Sheldrick, Acta Crystallogr. C 71 (2015) 3-8.

[26] L.J. Farrugia, J. Appl. Cryst. 45 (2012) 849-854.

[27] L.J. Farrugia, J. Appl. Crystallogr. 30 (1997) 565.

[28] R. Soni, J.M. Collinson, G.C. Clarkson, M. Wills, Org. Lett. 13 (2011) 4304-4307.

[29] (a) K. Saito, H. Miyashita, T. Akiyama, Org. Lett. 16 (2014) 53125315;

(b) C. Zhu, T. Akiyama, Org. Lett. 11 (2009) 4180-4183. 